\title{
ГЕНЕТИЧНІ АЛГОРИТМИ В ЗАДАЧАХ СИНТЕЗУ МАРШРУТІВ ТРАНСПОРТНИХ СИСТЕМ ГВС
}

Анотація: Розглядається проблема побудови транспортних маршрутів ГВС. Пропонується метод вирішення даної задачі як задачі комівояжера за допомогою генетичного алгоритму.

Ключові слова: синтез транспортних маршрутів ГВС, задача комівояжера, генетичний алгоритм

\section{Вступ}

Складність задачі синтезу маршрутів транспортних систем ГВС полягає у великій кількості складових та різноманітності маршрутів. Розглянемо ГВС, що складаеться із 10 верстатів, кожен із яких з'еднаний мінімум із двома іншими.

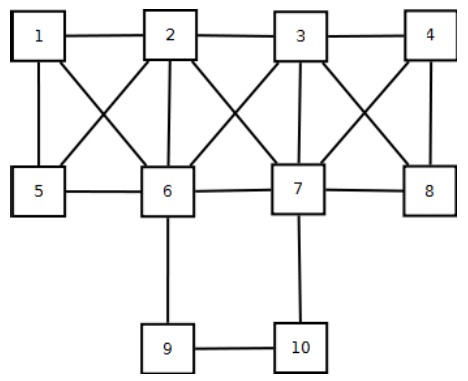

Рис. 1 - ГВС із 10 верстатів

Пошук транспортного маршруту від верстата 1 до 10 потребує вагомих обрахунків, а у випадку із ГВС, що складаеться зі 100 та більше верстатів, такі обрахунки можуть зайняти неприйнятно багато часу. Тому для рішення задач даного типу краще користуватись евристичними методами, які хоч і не дають найоптимальніший результат, а лише його наближення, потребують менше часу на обчислення.

Розглянемо задачу синтезу маршрутів транспортних систем ГВС, як задачу комівояжера, де кожен верстат являеться містом, а транспортна система між двома верстатами дорогою між містами.

Задача комівояжера визначається наступним чином: в області існуючих n точок(міст), з'єднаних дорогами, згідно принципу “кожен з кожним", а проїзд по дорозі характеризуеться певним вектором вартості. Задача комівояжера - пройти маршрут з мінімальним часом, коштами або відстанню.

(c) К.С. Гончарук, О.І. Лісовиченко, 2011 
Вперше задача комівояжера була сформульована Ейлером в 1759 і вирішувала проблему побудови маршруту переміщення коня шаховою дошкою таким чином, щоб не відвідати одну клітину двічі [1].

Вектор вартості маршруту в задачі буде складатись з трьох компонентів: пройдений час, час в дорозі та матеріальні витрати. Так як маршрут повинен проходити через кожне місто лише один раз, то вибір здійснюється серед гамільтонових циклів. Пошук гамільтонових циклів, являється NP-повною задачею [2].

\section{Постановка задачі}

Найпростіші методи рішення задачі комівояжера: повний лексичний перебір, “жадібні” алгоритми (метод найближчого сусіда, метод включення найближчого міста, метод найбільш дешевого включення), метод мінімального основного дерева. На практиці застосовуються різні модифікації найбільш ефективних методів: метод гілок та границь, а також алгоритм мурашиної колонії.

Дані методи мають ряд недоліків, а саме:

1. Жадібний алгоритм - висока похибка вибору оптимального шляху.

2. Мінімального основного дерева - необхідність побудови дерева зв'язків між усіма містами.

3. Метод гілок та границь - низька швидкість роботи.

4. Алгоритм лексичного перебору - низька швидкість роботи, доцільно використовувати лише при кількості міст від 5 до 12 .

Всі ефективні (в плані скорочення повного перебору) методи рішення задачі комівояжера евристичні. В більшості евристичних методів знаходиться на найбільш ефективний маршрут, а наближене значення. Найчастіше використовуються алгоритми, які постійно покращують певне наближене рішення. Прикладом таких евристичних методів є генетичний алгоритм.

Генетичний алгоритл - техніка оптимізації, що може бути застосована для вирішення багатьох задач, у тому числі задачі комівояжера. Алгоритм не забезпечує оптимального результату, але зазвичай похибка досить низька зважаючи на час роботи.

Обов’язкові складові генетичного алгоритму:

1. Особи (хромосоми). На відміну від інших алгоритмів оптимізації, генетичні алгоритми оперують не напряму з даними, а з їх репрезентацією у певному вигляді (наприклад у вигляді масиву або бінарному) - хромосомою. Хромосома - це сукупність генів(елементів результату), послідовність яких є одним із можливих варіантів вирішення задачі. У випадку із задачею комівояжера, геном буде місто, що відвідав комівояжер, а хромосомою весь маршрут. Для оцінки оптимальності (пристосованості) осіб використовуеться фрунцція оптимальності. Оцінка може проводитись як на базі одного критерію (в задачі комівояжера - довжина шляху, час в 
дорозі, вартість маршруту та ін.) так і на базі сукупності критеріїв. У випадку оцінки на базі декількох критеріїв проводиться їх комбінування в суперкритерій:

$$
F(x)=\sum_{i=0}^{n} a_{i} F_{i}(x),
$$

де $a_{i}>0$ - ваговий коефіцієнт; $F_{i}(x)$ - значення функції пристосованості по критерію.

2. Кросовер - операція поєднання пари хромосом в одну. Проводиться шляхом поділу кожної хромосоми по випадково обраним генам та поєднання результатів поділу в нову хромосому. Після проведення кросовера, проводиться відбір - аналог еволюційного відбору - процес, під час якого більш пристосовані особи залишаються, а найменш пристосовані вилучаються. Якщо ж в популяції е однакові особи, проводиться мутація - вибір із популяції однієї із схожих осіб та модифікація її випадково обраного гена.

Отже, вирішимо задачу комівояжера за допомогою генетичного алгоритму.

\section{Рішення проблеми}

Генетичний алгоритм базуеться на природній еволюції і техніці “виживає найбільш пристосований”, при якій найкращі рішення виживають і змінюються до досягнення найкращого результату. Для забезпечення процесу еволюції рішень використовуються оператори кросовера та мутації, а також фонкція оптимальності для визначення рівня пристосованості. Процес рішення задачі за допомогою генетичного алгоритму складаеться із наступних складових: 1 . кодування; 2 . оцінка якості; 3. кросовер; 4. мутація; 5 . декодування

Техніка кодування визначається індивідуально для кожної задачі таким чином, щоб за їі допомогою можна було закодувати кожен із можливих результатів рішення, а закодований результат можна було представити у вигляді стоки.

Початкова популяція генеруеться випадково і для кожної особи в ній, за допомогою функції оптимальності, визначаеться рівень пристосованості, який показуе наскільки добре кожен індивідуум може вирішити поточну задачу, наскільки він близький до оптимального, в порівнянні з іншими особами. Рівень пристосованості використовуеться для відбору осіб для кросовера. Чим більш пристосований індивід, тим більша ймовірність, що він буде відібраний.

Під час кросоверу дві особи комбінуються для створення нових індивідуумів, що будуть додані до популяції.

При присутності в популяції великої кількості подібних осіб, проводиться мутація, для забезпечення продовження роботи генетичного алгоритму.

Таким чином рішення задачі комівояжера за допомогою генетичного алгоритму складається із наступних етапів: 
1. генерація початкової популяції;

2. оцінка осіб;

3. кросовер;

4. мутація;

5. оцінка нових осіб;

6. відбір.

Кроки 3-6 повторюються доти, поки дозволяють часові обмеження.

Спробуемо застосувати апарат генетичного алгоритму для вирішення задачі комівояжера. Наприклад, е 16 міст, кожне з яких має зв'язок мінімум із двома іншими. Необхідно знайти оптимальний маршрут між містами 0 та 15.

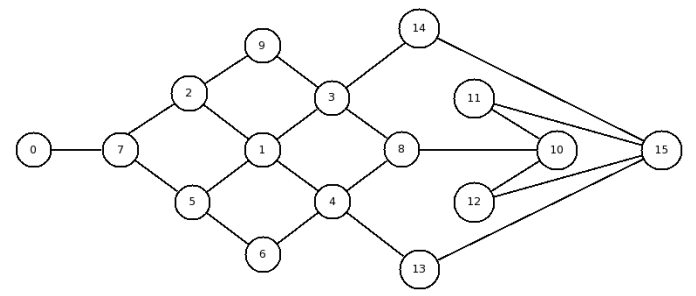

Рис. 2 - Мапа розташування міст за зв'язків між ними

За критерій оптимальності оберемо довжину маршруту.

Для налаштування генетичного алгоритму необхідно визначити об'ем популяції. Ці дані зазвичай знаходяться дослідним шляхом або в результаті попереднього досвіду [4].

Проведемо досліди для визначення оптимального об'єму початкової популяції при 10 кросоверах.

Таблиця 1

Залежність довжини оптимального маршруту від розміру початкової популяції

\begin{tabular}{|c|c|}
\hline Кількість осіб & Довжина оптимального маршруту \\
\hline 3 & 1523 \\
\hline 5 & 1271 \\
\hline 10 & 1117 \\
\hline 15 & 1088 \\
\hline 20 & 1088 \\
\hline 25 & 1088 \\
\hline
\end{tabular}

Як видно із таблиці, довжина оптимального маршруту найбільш пристосованої особи перестала зменшуватись починаючи з розміру популяції в 15 осіб. 
Згенеруємо початкову популяцію із 15 осіб:

$0->7->2->1->4->8->10->11->15$

$0->7->2->9->3->8->10->11->15$

$0->7->2->9->3->8->10->12->15$

$0->7->5->6->4->13->15$

$0->7->2->9->3->8->10->12->15$

$0->7->2->1->4->13->15$

$0->7->2->1->3->8->10->11->15$

$0->7->5->6->4->8->3->14->15$

$0->7->5->1->4->13->15$

$0->7->2->9->3->8->10->12->15$

$0->7->2->1->3->5->10->12->15$

$0->7->5->6->4->13->15$

$0->7->2->9->3->8->10->12->15$

$0->7->2->1->3->8->10->12->15$

Проведемо n кросоверів, для кожного з яких оберемо з популяції дві випадкові особи. Результат кросоверу збережемо в популяції, при цьому вилучивши найменш пристосовану особу. Це дозволить залишити розмір популяції незмінним, а також дасть можливість еволюції популяції, а разом з нею і оптимального рішення.

Рішенням задачі буде найбільш пристосована особа після завершення всіх кросоверів.

Побудуємо матрицю залежності результату від кількості кросоверів.

Таблиця 2

Залежність результату від розміру початкової популяції та кількості кросоверів

\begin{tabular}{|c|c|c|c|c|c|c|}
\hline особи кросовери & 3 & 5 & 10 & 15 & 20 & 25 \\
\hline 1 & 1557 & 1184 & 1115 & 1090 & 1100 & 1089 \\
\hline 5 & 1271 & 1182 & 1102 & 1086 & 1089 & 1081 \\
\hline 10 & 1186 & 1165 & 1092 & 1083 & 1083 & 1081 \\
\hline 15 & 1154 & 1132 & 1089 & 1078 & 1083 & 1080 \\
\hline 20 & 1129 & 1089 & 1088 & 1077 & 1077 & 1077 \\
\hline
\end{tabular}

Побудуемо графік залежності результату рішення задачі комівояжера від розміру початкової популяції та кількості кросоверів.

Очевидно, що розмір популяції та кількість кросоверів це взаемокомпенсуючі величини, тобто відсутність можливості згенерувати велику початкову популяцію можна компенсувати великою кількістю кросоверів і навпаки.

Після проведення 15 кросоверів найбільш пристосована особа і є оптимальним рішенням задачі: 0 -> 7 -> 2 -> 9 -> 3 -> $14->15$ 


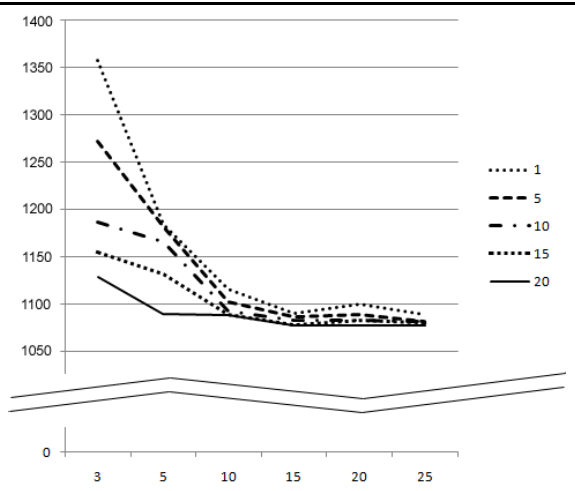

Рис. 3 - Графрік залежності результату від розміру початкової популяції та кількості кросоверів

Таким чином ми отримали оптимальну конфігурацію для даної задачі, яку можна використовувати в подальших жї модифікаціях(знаходження оптимальних маршрутів між іншими містами).

\section{Висновок}

Перевага використання генетичного алгоритму в порівнянні з іншими методами (наприклад методом повного перебору) стає очевидною при великій кількості міст. Наприклад при 10 містах, перебір буде включати 10 ! можливих шляхів, але при 100 містах 100 ! варіантів, тобто $9.3 e^{157}$ шляхів. Таким чином вирішення задачі із 100 міст методом повного перебору, в комп'ютера, що може опрацювати 1000000 шляхів в секунду займе $3 e^{144}$ роки. Тому не зважаючи на те, що генетичний алгоритм дає не оптимальний, а лише наближений до оптимального маршрут, його використання є доцільним завдяки перевазі в швидкості роботи.

\section{Література}

1. Стаття “Задача комівояжера" [http://ru.wikipedia.org/wiki /задача_комівояжера]

2. Weisstein E.W. Hamiltonian Circuit [http:// www.http:// mathworld. wolfram.com /HamiltonianCircuit.html]

3. Нейронні мережі, генетичні алгоритми та нечіткі системи / Рутковська Д., Пилинський М., Рутковський Л. // Гаряча лінія. - 2006. - С. 124-139.

4. The Royal Road for Genetic Algorithms: Fitness Landscapes and GA Performance / Холланд Дж.X // Збірник: Toward a Practice of Autonomous Systems; Видавництво: MIT Press. - 1992.

Отримано 03.03.2011 p. 